\title{
Aplikasi Asuhan Keperawatan Psikososial Pada Ny. F Dengan Masalah Kecemasan
}

\author{
Saleha \\ lehasleo07@gmail.com
}

BAB 1

PENDAHULUAN

\subsection{Latar Belakang}

Hipertensi adalah peningkatan tekanan darah sistolik lebih dari $140 \mathrm{mmHg}$ dan tekanan darah diastolik lebih dari $90 \mathrm{mmHg}$ pada dua kali pengukuran dengan selang waktu lima menit dalam keadaan cukup istirahat/tenang. Peningkatan tekanan darah dengan jangka waktu yang lama dapat menimbulkan kerusakan pada ginjal, jantung dan otak apabila tidak dilakukan pengobatan secara dini (Sofiana, 2018). Hipertensi merupakan suatu tantangan kesehatan masyarakat secara global, dimana dapat mengurangi kualitas hidup secara signifikan dan juga merupakan salah satu faktor risiko yang sangat berkaitan erat dengan penyakit kardiovaskuler dan mortalitas atau kematian pada usia muda akibat penyakit hipertensi (Akbar \& Tumiwa 2020).

World Health Organization (WHO) dan The International Society of Hypertension (ISH) menetapkan bahwa hipertensi merupakan kondisi ketika tekanan darah (TD) sistolik lebih besar dari $140 \mathrm{mmHg}$ dan tekanan diastolik lebih besar dari $90 \mathrm{mmHg}$. Nilai ini merupakan hasil rerata minimal dua kali pengukuran setelah melakukan dua kali atau lebih kontak dengan petugas (Yasmara, 2016). Berdasarkan data WHO (World Health Organization) menyebutkan bahwa hipertensi menyerang $22 \%$ penduduk dunia, dan mencapai 36\% angka kejadian di Asia Tenggara. Hipertensi juga menjadi penyebab kematian dengan angka $23,7 \%$ dari total 1,7 juta kematian di Indonesia tahun 2016 (Hariawan, 2020). 
Menurut data Riskesdas (2017). bahwa lansia yang mengalami kecemasan menyebabkan terjadinya peningkatan tekanan darah. Kecemasan adalah kekhawatiran yang tidak jelas dan menyebar yang berkaitan dengan perasaan tidak pasti dan tidak berdaya. Keadaan emosi ini tidak memiliki obyek yang spesifik. Gangguan kecemasan dan depresi di derita oleh 40 juta populasi orang dewasa di Amerika dan diprediksi 20\% dari populasi dunia menderita kecemasan (Kaplan \& Sadock, 2016).

Kecemasan adalah kekhawatiran yang tidak jelas dan menyebar, yang berkaitan dengan perasaan tidak pasti dan tidak berdaya. Keadaan emosi ini tidak memiliki objek yang spesifik. Kecemasan di alami secara subjektif dan dikomunikasikan secara interpersonal dapat menjadi suatu kekuatan motivasi untuk pertumbuhan dan perkembangan pada individu yang bersangkutan (Marbun, Pardede \& Perkasa, 2019). Berdasarkan survei awal yang telah dilakukan pada pasien di jalan Amal Luhur Gg. Supir, didapatkan keadaan pasien saat diajak komunikasi terlihat gelisah, bicaranya cepat dan kontak mata tidak fokus, saat dilakukan pemeriksaan Tanda-tanda vital didapatkan tekanan darah pasien tinggi, denyut nadi cepat. Saat ditanya mengapa terlihat gelisah, pasien menjawab khawatir akan penyakit Hipertensi nya dan umur yang kini semakin menua sehingga tidak bisa melakukan banyak aktivitas seperti biasanya.

\subsection{Tujuan}

\subsubsection{Tujuan Umum}

Berdasarkan latar belakang masalah tersebut maka dapat dirumuskan masalah sebagai berikut : Bagaimana Memberikan Asuhan Keperawatan Psikososial Pada Ny.F Dengan Masalah Kecemasan Di Jalan Amal Luhur Gg. Supir Medan Helvetia

\subsubsection{Tujuan Khusus}


1. Mahasiswa mampu mengetahui defenisi, tanda \& gejala, faktor penyebab, mekanisme koping, penatalaksanaan pada pasien dengan Hipertensi Pada Psikososial Kecemasan Di Jalan Amal Luhur Gg. Supir Medan Helvetia.

2. Mahasiswa mampu melakukan pengkajian pada pasien dengan Hipertensi Pada Psikososial Kecemasan Di Jalan Amal Luhur Gg. Supir Medan Helvetia.

3. Mahasiswa mampu menegakkan diagnosa atau masalah keperawatan pada Ny.F dengan Hipertensi Pada Psikososial Kecemasan Di Jalan Amal Luhur Gg. Supir Medan Helvetia.

4. Mahasiswa mampu menetapkan intervensi keperawatan secara menyeluruh pada Ny.F dengan Hipertensi Pada Psikososial Kecemasan Di Jalan Amal Luhur Gg. Supir Medan Helvetia.

5. Mahasiswa mampu melakukan tindakan keperawatan yang nyata pada Ny.F dengan Hipertensi Pada Psikososial Kecemasan Di Jalan Amal Luhur Gg. Supir Medan Helvetia.

6. Mahasiswa mampu mengevaluasi sebagai tolak ukur guna menerapkan asuhan keperawatan pada Ny.F dengan Hipertensi Pada Psikososial Kecemasan Di Jalan Amal Luhur Gg. Supir Medan Helvetia.

7. Mahasiswa mampu mendokumentasikan asuhan keperawatan pada Ny.F dengan Hipertensi Pada Psikososial Kecemasan Di Jalan Amal Luhur Gg. Supir Medan Helvetia.

\section{BAB 2}




\section{TINJAUAN TEORITIS}

\subsection{Konsep Hipertensi}

\subsubsection{Definisi}

Hipertensi adalah peningkatan tekanan darah sistolik lebih dari $140 \mathrm{mmHg}$ dan tekanan darah diastolik lebih dari $90 \mathrm{mmHg}$ pada dua kali pengukuran dengan selang waktu lima menit dalam keadaan cukup istirahat/tenang. Peningkatan tekanan darah dengan jangka waktu yang lama dapat menimbulkan kerusakan pada ginjal, jantung dan otak apabila tidak dilakukan pengobatan secara dini (Sofiana, 2018).

Faktor resiko Hipertensi adalah umur, jenis kelamin, riwayat keluarga, genetik (faktor resiko yang tidak dapat diubah/dikontrol), kebiasaan merokok, konsumsi garam, konsumsi lemak jenuh, penggunaan jelantah, kebiasaan konsumsi minum-minuman beralkohol, obesitas, kurang aktifitas fisik, stres, penggunaan estrogen.

Berdasarkan penyebabnya hipertensi terbagi menjadi dua golongan :

a. Hipertensi primer atau hipertensi esensial

Hipertensi primer atau hipertensi esensial disebut juga hipertensi idiopatik karena tidak diketahui penyebabnya. Faktor yang memengaruhi yaitu :

1) Genetik

Individu yang mempunyai riwayat keluarga dengan hipertensi, beresiko tinggi untuk mendapatkan penyakit ini. Faktor genetik ini tidak dapat dikendalikan, jika memiliki riwayat keluarga yang memliki tekanan darah tinggi.

2) Jenis kelamin dan usia

Laki - laki berusia 35- 50 tahun dan wanita menopause beresiko tinggiuntuk mengalami hipertensi. Jika usia bertambah maka tekanan darah meningkat faktor ini tidak dapat dikendalikan serta jenis kelamin laki-laki lebih tinggi dari pada perempuan 
3) Diet

Konsumsi diet tinggi garam secara langsung berhubungan dengan berkembangnya hipertensi. Faktor ini bisa dikendalikan oleh penderita dengan mengurangi konsumsinya, jika garam yang dikonsumsi berlebihan, ginjal yang bertugas untuk mengolah garam akan menahan cairan lebih banyak dari pada yang seharusnya didalam tubuh. Banyaknya cairan yang tertahan menyebabkan peningkatan pada volume darah. Beban ekstra yang dibawa oleh pembuluh darah inilah yang menyebabkan pembuluh darah bekerja ekstra yakni adanya peningkatan tekanan darah didalam dinding pembuluh darah dan menyebabkan tekanan darah meningkat.

4) Berat badan

Faktor ini dapat dikendalikan dimana bisa menjaga berat badan dalam keadaan normal atau ideal. Obesitas $(>25 \%$ diatas BB ideal) dikaitkan dengan berkembangnya peningkatan tekanan darah atau hipertensi.

5) Gaya hidup

Faktor ini dapat dikendalikan dengan pasien hidup dengan pola hidup sehat dengan menghindari faktor pemicu hipertensi yaitu merokok, dengan merokok berkaitan dengan jumlah rokok yang dihisap dalam waktu sehari dan dapat menghabiskan berapa putung rokok dan lama merokok berpengaruh dengan tekanan darah pasien. Konsumsi alkohol yang sering, atau berlebihan dan terus menerus dapat meningkatkan tekanan darah pasien sebaiknya jika memiliki tekanan darah tinggi pasien diminta untuk menghindari alkohol agar tekanan darah pasien dalam batas stabil dan pelihara gaya hidup sehat penting agar terhindar dari komplikasi yang bisa terjadi.

b. Hipertensi sekunder

Hipertensi sekunder terjadi akibat penyebab yang jelas.salah satu 
contoh hipertensi sekunder adalah hipertensi vaskular rena, yang terjadiakibat stenosi arteri renalis. Kelainan ini dapat bersifat kongenital atau akibat aterosklerosis.stenosis arteri renalis menurunkan aliran darah ke ginjalsehingga terjadi pengaktifan baroreseptor ginjal, perangsangan pelepasn renin, dan pembentukan angiostenin II. Angiostenin II secara langsung meningkatkan tekanan darahdan secara tidak langsung meningkatkan sintesis andosteron danreabsorbsi natrium. Apabiladapat dilakukan perbaikan pada stenosis,atau apabila ginjal yang terkena diangkat, tekanan darah akan kembali ke normal.

\subsubsection{Patofisiologi}

Tekanan darah merupakan hasil interaksi antara curah jantung (cardiac out put) dan derajat dilatasi atau konstriksi arteriola (resistensi vascular sistemik). Tekanan darah arteri dikontrol dalam waktu singkat oleh baroreseptor arteri yang mendeteksi perubahan tekanan pada arteri utama, dan kemudian melalui mekanisme umpan balik hormonal menimbulkan berbagai variasi respons tubuh seperti frekuensi denyut jantung, kontraksi otot jantung, kontraksi otot polos pada pembuluh darah dengan tujuan mempertahankan tekanan darah dalam batas normal. Baroreseptor dalam komponen kardiovaskuler tekanan rendah, seperti vena, atrium dan sirkulasi pulmonary, memainkan peranan penting dalam pengaturan hormonal volume vaskuler. Penderita hipertensi dipastikan mengalami peningkatan salah satu atau kedua komponen ini, yakni curah jantung dan atau resistensi vascular sistemik (Nugraha, 2016)

Hemodinamik yang khas dari hipertensi yang menetap bergantung pada tingginya tekanan arteri, derajat kontriksi pembuluh darah, dan adanya pembesaran jantung. Hipertensi sedang yang tidak disertai dengan pembesaran jantung memiliki curah jantung normal. Namun demikian, terjadi peningkatan resistensi vaskukar perifer dan penurunan kecepatan ejeksi ventrikel kiri (Nugraha, 2016). 
Saat hipertensi bertambah berat dan jantung mulai mengalami pembesaran, curah jantung mengalami penurunan secara progresif meskipun belum terdapat tanda-tanda gagal jantung. Hal ini disebabkan resistensi perifer sistemik semakin tinggi dan kecepatan ejeksi ventrikel kiri semakin menurun (Nugraha, 2016). Penurunan curah jantung ini akan menyebabkan gangguan perfusi ke berbagai organ tubuh, terutama ginjal. Kondisi ini berdampak pada penurunan volume ekstra sel dan perfusi ginjal yang berujung dengan iskemik ginjal. Penurunan perfusi ginjal ini akan mengaktivasi system renin angiostensin (Nugraha, 2016).

Renin yang dikeluarkan oleh ginjal ini merangsang angiotensinogen untuk mengeluarkan angiotensinogen I (AI) yang bersifat vasokonstriktor lemah. Adanya angiotensin I pada peredaran darah akan memicu pengeluaran angiotensin converting enzyme (ACE) di endotelium pembuluh paru.

\subsubsection{Manifestasi Klinis}

Tahapan awal pasien kebanyakan tidak memiliki keluhan. Keadaan simtomatik maka pasien biasanya peningkatan tekanan darah disertai berdebar- debar, rasa melayang (dizzy) dan impoten. Hipertensi vaskuler terasa tubuh cepat untuk merasakan capek, sesak nafas, sakit pada bagian dada, bengkak pada kedua kaki atau perut (Setiati, Alwi, Sudoyo, Simadibrata, Syam, 2014). Gejala yang muncul sakit kepala, pendarahan pada hidung, pusing, wajah kemerahan, dan kelelahan yang bisa terjadi saat orang menderita hipertensi (Irianto, 2014).

Hipertensi dasar seperti hipertensi sekunder akan mengakibatkan penderita tersebut mengalami kelemahan otot pada aldosteronisme primer, mengalami peningkatan berat badan dengan emosi yang labil pada sindrom cushing, polidipsia, poliuria. Feokromositoma dapat muncul dengan keluhan episode sakit kepala, palpitasi, banyak keringat dan rasa melayang saat berdiri (postural dizzy). Saat hipertensi terjadi sudah lama pada penderita atau 
hipertensi sudah dalam keadaan yang berat dan tidak diobati gejala yang timbul yaitu sakit kepala, kelelahan, mual, muntah, sesak nafas, gelisah, pandangan menjadi kabur. Semua itu terjadi karena adanya kerusakan pada otak, mata, jantung dan ginjal. Pada penderita hipertensi berat mengalami penurunan kesadaran dan bahkan mengakibatkan penderita mengalami koma karena terjadi pembengkakan 17 pada bagian otak. Keadaan tersebut merupakan keadaan ensefalopati hipertensi (Irianto, 2014)

\subsubsection{Komplikasi}

Tekanan darah tinggi bila tidak segera diobati atau ditanggulangi, dalam jangka panjang akan menyebabkan kerusakan ateri didalam tubuh sampai organ yang mendapat suplai darah dari arteri tersebut Komplikasi yang dapat terjadi pada penderita hipertensi yaitu :

a. Stroke terjadi akibat hemoragi disebabkan oleh tekanan darah tinggi di otak dan akibat embolus yang terlepas dari pembuluh selain otak yang terpajan tekanan darah tinggi.

b. Infark miokard dapat terjadi bila arteri koroner yang arterosklerotik tidak dapat menyuplai cukup oksigen ke miokardium dan apabila membentuk 12 trombus yang bisa memperlambat aliran darah melewati pembuluh darah. Hipertensi kronis dan hipertrofi ventrikel, kebutuhan oksigen miokardium tidak dapat dipenuhi dan dapat terjadi iskemia jantung yang menyebabkan infark. Sedangkan hipertrofi ventrikel dapat menyebabkan perubahan waktu hantaran listrik melintasi ventrikel terjadilah disritmia, hipoksia jantung, dan peningkatan resiko pembentukan bekuan.

c. Gagal jantung dapat disebabkan oleh peningkatan darah tinggi. Penderita hipertensi, beban kerja jantung akan meningkat, otot jantung akan mengendor dan berkurang elastisitasnya, disebut dekompensasi. Akibatnya jantung tidak mampu lagi memompa, banyak cairan tertahan diparu yang dapat menyebabkan sesak nafas (eudema) kondisi ini disebut gagal jantung. 
d. Ginjal tekanan darah tinggi bisa menyebabkan kerusakan ginjal. Merusak sistem penyaringan dalam ginjal akibat ginjal tidak dapat membuat zat-zat yang tidak dibutuhkan tubuh yang masuk melalui aliran darah dan terjadi penumpukan dalam tubuh.

\subsection{Konsep Kecemasan}

\subsubsection{Definisi}

Kecemasan merupakan suatu keadaan perasaan gelisah, ketidaktentuan, ada rasa takut dari kenyataan atau persepsi ancaman sumber aktual yang tidak diketahui masalahnya (Pardede \& Simangunsong, 2020). Kecemasan merupakan suatu respon psikologis maupun fisiologis individu terhadap suatu keadaan yang tidak menyenangkan, atau reaksi atas situasi yang dianggap mengancam (Hulu \& Pardede, 2016).

Kecemasan adalah pengalaman subjektif dari ketegangan mental yang mengganggu sebagai reaksi umum dan ketidakmampuan untuk menghadapi masalah atau adanya rasa tidak aman. Perasaan tidak menyenangkan umumnya menimbulkan gejala fisiologis (seperti gemetar, berkeringat, detak jantung meningkat, dll) dan gejala psikologis seperti panik, tegang, bingung, tidak dapat berkonsentrasi, dll (Pardede, Simanjuntak, \& Manalu 2020).

Kecemasan adalah keadaan emosi tanpa objek tertentu. Kecemasan dipicu oleh hal yang tidak diketahui dan menyertai semua pengalaman baru, seperti masuk sekolah, memulai pekerjaan baru atau melahirkan anak. Karakteristik kecemasan ini yang membedakan dari rasa takut. Kecemasan merupakan suatu perasaan subjektif mengenai ketegangan mental yang menggelisahkan sebagai reaksi umum dari ketidakmampuan mengatasi suatu masalah atau tidak adanya rasa aman. Perasaan yang tidak menentu tersebut pada umumnya tidak menyenangkan yang nantinya akan menimbulkan perubahan fisiologis dan psikologis. Kecemasan dalam pandangan kesehatan juga merupakan suatu keadaan yang menggoncang karena adanya ancaman terhadap kesehatan 
(Stuart \& Sundeen, 2016)

Kecemasan adalah suatu perasaan takut akan terjadinya sesuatu yang disebabkan oleh antisipasi bahaya dan merupakan sinyal yang membantu individu untuk bersiap mengambil tindakan menghadapi ancaman. Pengaruh tuntutan, persaingan, serta bencana yang terjadi dalam kehidupan dapat membawa dampak terhadap kesehatan fisik dan psikologi. Salah satu dampak psikologis yaitu ansietas atau kecemasan (Sutejo, 2018). Kecemasan merupakan suatu keadaan perasaan gelisah, ketidaktentuan, ada rasa takut dari kenyataan atau persepsi ancaman sumber aktual yang tidak diketahui masalahnya (Pardede \& Simangunsong, 2020).

\subsubsection{Etiologi}

Meski penyebab kecemasan belum sepenuhnya diketahui, namun gangguan keseimbangan neurotransmitter dalam otak dapat menimbulkan ansietas pada diri seseorang. Faktor genetik juga merupakan faktor yang dapat menimbulkan gangguan ini. Kecemasan terjadi ketika seseorang mengalami kesulitan menghadapi situasi, masalah dan tujuan hidup. Setiap individu menghadapi stres dengan cara yang berbeda-beda, seseorang dapat tumbuh dalam suatu situasi yang dapat menimbulkan stres berat pada orang lain. Adapun faktor-faktor yang mempengaruhi kecemasan (Setyaningsih, 2015) adalah :

2. Faktor Predisposisi

Stressor predisposisi adalah semua ketegangan dalam kehidupan yang dapat menyebabkan timbulnya kecemasan. Ketegangan dalam kehidupan tersebut dapat berupa :

a. Peristiwa Traumatik, yang dapat memicu terjadinya kecemasan berkaitan dengan krisis yang dialami individu baik krisis perkembangan atau situasional. 
b. Konflik Emosional, yang dialami individu dan tidak terselesaikan dengan baik. Konflik antara id dan superego atau antara keinginan dan kenyataan dapat menimbulkan kecemasan pada individu.

c. Konsep diri terganggu akan menimbulkan ketidakmampuan individu berpikir secara realitas sehingga akan menimbulkan kecemasan.

d. Frustasi akan menimbulkan rasa ketidakberdayaan untuk mengambil keputusan yang berdampak terhadap ego.

e. Gangguan fisik akan menimbulkan kecemasan karena merupakan ancaman terhadap integritas fisik yang dapat mempengaruhi konsep diri individu.

f. Pola mekanisme koping keluarga atau pola keluarga menangani stress akan mempengaruhi individu dalam berespon terhadap konflik yang dialami karena pola mekanisme koping individu banyak dipelajari dalam keluarga.

g. Riwayat gangguan kecemasan dalam keluarga akan mempengaruhi respons individu dalam berespons terhadap konflik dan mengatasi kecemasannya.

h. Medikasi yang dapat memicu terjadinya kecemasan adalah pengobatan yang mengandung benzodiazepin, karena benzodiazepine dapat menekan neurotransmiter gamma amino butyric acid (GABA) yang mengontrol aktivitas neuron di otak yang bertanggung jawab menghasilkan kecemasan.

3. Faktor presipitasi

Stresor presipitasi adalah semua ketegangan dalam kehidupan yang dapat mencetuskan timbulnya kecemasan (Setyaningsih, 2015). Stressor presipitasi kecemasan dikelompokkan menjadi dua bagian, yaitu

a. Ancaman terhadap integritas fisik. Ketegangan yang mengancam integritas fisik yang meliputi :

- Sumber Internal, meliputi kegagalan mekanisme fisiologis sistem imun, regulasi suhu tubuh, perubahan biologis normal (misalnya : hamil). 
- Sumber Eksternal, meliputi paparan terhadap infeksi virus dan bakteri, polutan lingkungan, kecelakaan, kekurangan nutrisi, tidak adekuatnya tempat tinggal.

b. Ancaman terhadap harga diri meliputi sumber internal dan eksternal

- Sumber Internal : kesulitan dalam berhubungan interpersonal di rumah dan tempat kerja, penyesuaian terhadap peran baru. Berbagai ancaman terhadap integritas fisik juga dapat mengancam harga diri.

- Sumber Eksternal : kehilangan orang yang dicintai, perceraian, perubahan status pekerjaan, tekanan kelompok, sosial budaya.

\subsubsection{Tingkat Kecemasan}

\section{Ansietas Ringan}

Ansietas ringan berhubungan dengan ketengan akan peristiwa kehidupan sehari-hari. Pada tingkat ini laangan persepsi melebar dan individu terdorong untuk belajar yang akan menghasilkan pertumbuhan kreatifitas. (Bulechek, 2016).

a. Respon fisiologis

1. Sesekali napas pendek

2. Nadi dan tekanan darah naik

3. Gejala ringan pada lambung

4. Muka berkerut dan bibir bergetar

b. Respon kognitif

1. Lapang persepsi melebar

2. Mampu menerima rangsangan yang kompleks

3. Konsentrasi pada maslah

4. Menejlaskan masalah secara efektif

c. Respon perilaku dan emosi

1. Tidak dapat duduk tenang

2. Tremor halus pada tangan

3. Suara kadang-kadang meninggi

2. Ansietas sedang 
Pada tingkat ini lapangan persepsi terhadap lingkugan menurun. Individu lebih memfokuskan hal-hal penting dan mengenyampingkan hal-hal lain (Bulechek, 2016).

a. Respon fisiologis

1. Nadi (ekstra systole) dan tekanan darah naik

2. Mulut kering

3. Anorexia

4. Diare/konstipasi

5. Gelisah

b. Respon kognitif

1. Lapang persepsi menyempit

2. Rangsang luar tidak mampu diterima

3. Berfokus pada apa yang menjadi perhatian

c. Respon perilaku dan emosi

1. Gerakan tersentak-sentak (meremas tangan)

2. Bicara banyak dan lebih cepat

3. Susah tidur

4. Perasaan tidak aman

3. Ansietas berat

Pada ansietas berat lapangan persepsi menjadi sangat sempit, individu cenderung memikirkan hal yang kecil saja dan mengabaikan hal lain,individu tidak mampu lagi berpikir realistis dan membutuhkan pengarahan untuk memusatkan perhatian pada area lain (Bulechek, 2016).

a. Respon fisiologi

1. Sering nafas pendek Nadi dan tekanan darah naik

2. Berkeringat dan sakit kepala

3. Penglihatan kabur

4. Ketegangan

b. Respon kognif

1. Lapang persepsi sangat sempit

2. Tidak mampu menyelesaikan masalah 
3. Respon perilaku dan emosi

4. Perasaan ancam meningkat

5. Verbialisasi cepat

6. Blocking

\subsubsection{Mekanisme Koping}

Ketika pasien mengalami ansietas, individu menggunakan bermacam macam mekanisme koping untuk mencoba mengatasinya. Dalam bentuk ringan ansietas bentuk ringan ansietas dapat di atasi dengan menangis, tertawa, tidur, olahraga atau merokok. Bila terjadi ansietas berat sampai panik akan terjadi ketidakmampuan mengatasi ansietas secara konstruktif merupakan penyebab utama perilaku yang patologis, individu akan menggunakan energy yang lebih besar untuk dapat mengatasi ancaman tersebut.

Mekanisme koping untuk mengatasi ansietas adalah:

1. Reaksi yang berorientasi pada tugas (task oriented reaction) Merupakan pemecahan masalah secara sadar yang digunakan untuk menanggulangi ancaman stressor yang ada secara realistis yaitu:

a. Perilaku menyerang (Agresif) Biasanya digunakan individu untuk mengatasi rintangan agar memenuhi kebutuhan.

b. Perilaku menarik diri Digunakan untuk menghilangkan sumber ancaman baik secara fisik maupun psikologis.

c. Perilaku kompromi Digunakan untuk merubah tujuan yang akan dilakukan atau mengorbankan kebutuhan personal untuk mencapai tujuan.

1. Mekanisme pertahanan ego (Ego oriented reaction) Mekanisme ini membantu mengatasi ansietas ringan dan sedang yang digunakan untuk melindungi diri dan dilakukan secara sadar untuk mempertahankan keseimbangan. Mekanisme pertahanan ego: 
a. Disosiasi adalah pemisahan dari proses mental atau perilaku dari kesadaran atau identitasnya.

b. Identifikasi (identification) adalah proses dimana seseorang untuk menjadi yang ia kagumi berupaya dengan mengambil/meniru pikiranpikiran, perilaku dan selera orang tersebut.

c. Intelektualisasi (intellectualization) adalah penggunaan logika dan alasan yang berlebihan untuk menghindari pengalaman yang mengganggu perasaannya.

d. Introjeksin (introjection) adalah suatu jenis identifikasi yang dimana seseorang mengambil dan melebur nilai-nilai dan kualitas seseorang atau suatu kelompok kedalam struktur egonya sendiri, berupa hati nurani, contohnya rasa benci atau kecewa terhadap kematian orang yang dicintai, dialihkan dengan cara menyalahkan diri sendiri.

e. Kompensasi adalah proses dimana seseorang memperbaiki penurunan citra diri dengan secara tegas menonjolkan keistimewaan/kelebihan yang dimilikinya. Penyangkalan (Denial) adalah menyatakan ketidaksetujuan terhadap realitas dengan mengingkari realitas tersebut. Mekanisme pertahanan ini adalah penting, sederhana, primitif.

f. Pemindahan (displacement) adalah pengalihan emosi yang semula ditujukan pada seseorang/benda kepada orang lain/benda lain yang biasanya netral atau kurang mengancam dirinya.

g. Isolasi adalah pemisahan unsur emosional dari suatu pikiran yang menggangu dapat bersifat sementara atau berjangka lama.

h. Proyeksi adalah pengalihan buah pikiran atau impuls pada diri sendiri kepada orang lain terutama keinginan, perasaan emosional dan motivasi yang tidak dapat ditoleransi.

i. Rasionalisasi adalah mengemukakan penjelasan yang tampak logis dan dapat diterima masyarakat untuk membenarkan perasaan perilaku dan motif yang tidak dapat diterima. 
j. Reaksi formasi adalah pengembangan sikap dan pola perilaku yang ia sadari yang bertentangan dengan apa yang sebenarnya ia rasakan atau ingin dilakukan.

k. Regresi adalah kemunduran akibat stress terhadap perilaku dan merupakan ciri khas dari suatu taraf perkembangan yang lebih dini.

1. Represi adalah pengenyampingkan secara tidak sadar tentangtentang pikiran, ingatan yang menyakitkan atau bertentangan ,dari kesadaran seseorang merupakan pertahanan ego yang primer yang cenderung diperkuat oleh mekanisme lain

\subsection{Konsep Asuhan Keperawatan}

\subsubsection{Pengkajian}

\section{Faktor Predisposisi}

Berbagai teori telah dikembangkan untuk menjelaskan asal ansietas

Stuart, Keliat \& Pasaribu (2016) :

a. Teori Psikoanalitik

Ansietas adalah konflik emosional yang terjadi antara dua elemen kepribadian, ID dan superego. ID mewakili dorongan insting dan impuls primitif seseorang, sedangkan superego mencerminkan hati nurani seseorang dan dikendalikan oleh norma- norma budaya seseorang. Ego atau Aku, berfungsi menengahi hambatan dari dua elemen yang bertentangan dan fungsi ansietas adalah mengingatkan ego bahwa ada bahaya.

b. Teori Interpersonal

Ansietas timbul dari perasaan takut terhadap tidak adanya penerimaan dari hubungan interpersonal. Ansietas juga berhubungan dengan perkembangan, trauma seperti perpisahan dan kehilangan sehingga menimbulkan kelemahan spesifik. Orang dengan harga diri rendah mudah mengalami perkembangan ansietas yang berat.

c. Teori Perilaku 
Ansietas merupakan produk frustasi yaitu segala sesuatu yang mengganggu kemampuan seseorang untuk mencapai tujuan yang diinginkan.Daftar tentang pembelajaran meyakini bahwa individu yang terbiasa dalam kehidupan dininya dihadapkan pada ketakutan yng berlebihan lebih sering menunjukkan ansietas pada kehidupan selanjutnya.

d. Kajian Keluarga

Menunjukkan bahwa gangguan ansietas merupakan hal yang biasa ditemui dalam suatu keluarga.Ada tumpang tindih dalam gangguan ansietas dan antara gangguan ansietas dengan depresi.

e. Kajian Biologis

Menunjukkan bahwa otak mengandung reseptor khusus benzodiazepine. Reseptor ini mungkin membantu mengatur ansietas penghambat dalam aminobutirik. Gamma neuroregulator (GABA) juga mungkin memainkan peran utama dalam mekanisme biologis berhubungan dengan ansietas sebagaimana halnya endorfin. Selain itu telah dibuktikan kesehatan umum seseorang mempunyai akibat nyata sebagai predisposisi terhadap ansietas. Ansietas mungkin disertai dengan gangguan fisik dan selanjutnya menurunkan kapasitas seseorang untuk mengatasi stressor.

\section{Faktor Presipitasi}

Stressor pencetus mungkin berasal dari sumber internal atau eksternal. Stressor pencetus dapat dikelompokkan menjadi 2 kategori :

a. Ancaman terhadap integritas seseorang meliputi ketidakmampuan fisiologis yang akan datang atau menurunnya kapasitas untuk melakukan aktifitas hidup sehari- hari.

b. Ancaman terhadap sistem diri seseorang dapat membahayakan identitas, harga diri dan fungsi sosial yang terintegrasi seseorang.

3. Perilaku 
Kecemasan dapat diekspresikan secara langsung melalui perubahan fisiologi dan perilaku dan secara tidak langsung melalui timbulnya gejala atau mekanisme koping dalam upaya melawan kecemasan. Intensitas perilaku akan meningkat sejalan dengan peningkatan tingkat kecemasan.

a. Respon Fisiologis Terhadap Ansietas

\begin{tabular}{|c|c|}
\hline Sistem Tubuh & Respons \\
\hline Kardiovaskuler & $\begin{array}{l}\text { - Palpitasi. } \\
\text { - Jantung berdebar. } \\
\text { - Tekanan darah meningkat dan denyut nadi menurun. } \\
\text { - Rasa mau pingsan dan pada akhirnya pingsan. }\end{array}$ \\
\hline Pernafasan & $\begin{array}{l}\text { - } \\
\text { - } \quad \text { Pernapasan dangkal. } \\
\text { - } \quad \text { Rasa tertekan pada dada. } \\
\text { - } \quad \text { Pembengkakan pada tenggorokan. } \\
\text { - } \quad \text { Rasa tercekik. } \\
\text { - } \quad \text { Terengah-engah. }\end{array}$ \\
\hline Neuromuskular & $\begin{array}{l}\text { - } \text { Peningkatan reflek. } \\
\text { - } \text { Reaksi kejutan. } \\
\text { - } \text { Insomnia. } \\
\text { - Ketakutan. } \\
\text { - Gelisah. } \\
\text { - } \text { Wajah tegang. } \\
\text { - Kelemahan secara umum. } \\
\text { - Gerakan lambat. } \\
\text { - Gerakan yang janggal. }\end{array}$ \\
\hline Gastrointestinal & - Kehilangan nafsu makan. \\
\hline
\end{tabular}




\begin{tabular}{|c|c|}
\hline & $\begin{array}{l}\text { - Menolak makan. } \\
\text { - Perasaan dangkal. } \\
\text { - Rasa tidak nyaman pada abdominal. } \\
\text { - Rasa terbakar pada jantung. } \\
\text { - Nausea. } \\
\text { - } \text { Diare. }\end{array}$ \\
\hline Perkemihan & $\begin{array}{l}\text { - } \text { Tidak dapat menahan kencing. } \\
\text { - Sering kencing. }\end{array}$ \\
\hline Kulit & $\begin{array}{l}\text { - } \text { Rasa terbakar pada mukosa. } \\
\text { - } \text { Berkeringat banyak pada telapak tangan. } \\
\text { - Gatal-gatal. } \\
\text { - Perasaan panas atau dingin pada kulit. } \\
\text { - Muka pucat dan bekeringat diseluruh tubuh. }\end{array}$ \\
\hline
\end{tabular}

b. Respon Perilaku Kognitif

\begin{tabular}{|l|l|}
\hline \multicolumn{1}{|c|}{ Sistem } & \multicolumn{1}{c|}{ Respons } \\
\hline Perilaku & $\bullet$ Gelisah. \\
& • Ketegangan fisik. \\
& $\bullet$ Tremor. \\
& - Gugup. \\
& - Bicara cepat. \\
& • Tidak ada koordinasi. \\
& - Mecenderungan untuk celaka. \\
& - Menghindar. \\
& - Terhambat melakukan aktifitas. \\
\hline
\end{tabular}




\begin{tabular}{|c|c|}
\hline \multirow[t]{2}{*}{ Kognitif } & $\begin{array}{l}\text { - } \text { Gangguan perhatian. } \\
\text { - } \text { Konsentrasi hilang. } \\
\text { - } \text { Pelupa. } \\
\text { - } \text { Salah tafsir. } \\
\text { - } \text { Adanya bloking pada pikiran. } \\
\text { - Kreatif dan produktif menurun. } \\
\text { - Bingung. }\end{array}$ \\
\hline & $\begin{array}{l}\text { - Khawatir yang berlebihan. } \\
\text { - } \quad \text { Hilang menilai objektifitas. } \\
\text { - Takut akan kehilangan kendali. } \\
\text { - Takut yang berlebihan. }\end{array}$ \\
\hline Afektif & $\begin{array}{l}\text { - } \text { Mudah terganggu. } \\
\text { - } \text { Tidak sabar. } \\
\text { - Gelisah. } \\
\text { - } \text { Tegang. } \\
\text { - Nerveus. } \\
\text { - Ketakutan. } \\
\text { - } \text { Alarm. } \\
\text { - Tremor. } \\
\text { - Gugup. } \\
\text { - Gelisah. }\end{array}$ \\
\hline
\end{tabular}

\section{Sumber Koping}

Individu dapat mengalami stress dan ansietas dengan menggerakkan sumber koping tersebut di lingkungan. Sumber koping tersebut sebagai modal ekonomok, kemampuan penyelesaian masalah, dukungan sosial dan keyakinan budaya dapat membantu seseorang mengintegrasikan 
pengalaman yang menimbulkan stress dan mengadopsi strategi koping yang berhasil.

\section{Mekanisme Koping}

Ketika mengalami ansietas individu menggunakan berbagai mekanisme koping untuk mencoba mengatasinya dan ketidakmampuan mengatasi ansietas secara konstruktif merupakan penyebab utama terjadinya perilaku patologis. Ansietas tingkat ringan sering ditanggulangi tanpa yang serius.

Tingkat ansietas sedang dan berat menimbulkan 2 jenis mekanisme koping :

a. Reaksi yang berorientasi pada tugas, yaitu upaya yang disadari dan berorientasi pada tindakan untuk memenuhi secara realitis tuntutan situasi stress.

b. Mekanisme pertahanan ego, membantu mengatasi ansietas ringan dan sedang, tetapi jika berlangsung pada tingkat sadar dan melibatkan penipuan diri dan distorsi realitas, maka mekanisme ini dapat merupakan respon maladaptif terhadap stress.

\subsubsection{Diagnosa Keperawatan}

Adapun diagnosa yang biasanya muncul adalah Stuart, Keliat \& Pasaribu (2016) :

1. Koping Individu Tidak Efektif

2. Kecemasan

3. Ketidakberdayaan

4. Isolasi Sosial

5. Perubahan Proses Berfikir

\subsubsection{Intervensi Keperawatan}

\section{Kecemasan}

Tujuan : 
a) Klien mampu mengenal pengertian penyebab tanda gejala dan akibat

b) Klien mampu mengetahui cara mengatasi ansietas

c) Klien mampu mengatasi ansietas dengan melakukan latihan relaksasi tarik nafas dalam

d) Klien mampu mengatasi ansietas dengan melakukan latihan distraksi

e) Klien mampu mengatasi ansietas dengan melakukan hipnotis lima jari

f) Klien mampu merasakan manfaat dari latihan yang dilakukan

g) Klien mampu membedakan perasaan sebelum dan sesudah latihan

Tindakan :

a. Kaji tanda dan gejala ansietas dan kemampuan klien mengurangi kecemasan

b. Jelaskan tanda dan gejala, penyebab dan akibat dari kecemasan

c. Latihan cara mengatasi kecemasan :

1) Teknik relaksasi napas dalam

2) Distraksi : bercakap-cakap hal positif

3) Hipnotis 5 jari fokus padahal-hal yang positif

d. Bantu klien melakukan latihan sesuai dengan jadwal kegiatan.

\section{Koping tidak efektif}

Tujuan :

Klien mampu mengetahui perubahan kondisi kesehatan dan kemampuannya mengatasi perubahan

Klien mampu mengetahui pengertian tanda dan gejala penyebab serta akibat dari ketidakefektifan koping

Klien mampu mengetahui cara mengatasi ketidakefektifan koping

Klien mampu mengatasi masalah secara bertahap

Klien mampu menggunakan sumber/daya sistem pendukung dalam 
mengatasi masalah

Klien mampu merasakan manfaat latihan yang dilakukan

Klien mampu mengembangkan koping yang efektif klien mampu merasakan manfaat sistem pendukung

Tindakan :

a. Kaji tanda dan gejala ketidakefektifan koping

b. Jelaskan proses terjadinya ketidakefektifan koping

c. Diskusikan koping (upaya atau cara) mengatasi masalah pada masa lalu

d. Koping (upaya) yang berhasil dan tidak berhasil. Berikan pujian

e. Pemanfaatan sumber daya atau sistem pendukung dalam mengatasi masalah

f. Latihan menggunakan upaya menyelesaikan masalah saat ini dengan menggunakan cara lama yang berhasil atau cara baru.

- Buat daftar masalah yang dihadapi

- Buat daftar cara (lama dan baru) yang akan digunakan

- Pilih, latih, dan jadwalkan cara yang akan digunakan untuk masalah yang dihadapi

- Evaluasi hasil jika berhasil dibudidayakan jika kurang berhasil dipilih cara lain pada daftar cara nomor kedua

g. Latih menggunakan sistem pendukung yang teratur

h. Beri motivasi dan pujian atas keberhasilan klien mengatasi masalah

\subsubsection{Implementasi keperawatan}

Merupakan inisiatif dari rencana tindakan untuk mencapai tujuan yang spesifik. Tahap pelaksanaan dimulai dimulai setelah rencana tindakan disusun dan ditujukan pada nursing orders untuk membantu klien mencapai tujuan yang diharapkan. Oleh karena itu rencana tindakan yang spesifik dilaksanakan untuk memodifikasi faktor-faktor yang mempengaruhi masalah kesehatan klien (Stuart, Keliat \& Pasaribu, 2016) 
Adapun tahap-tahap dalam tindakan keperawatan adalah sebagai berikut :

Tahap 1 : persiapan Tahap awal tindakan keperawatan ini menuntut perawat untuk mengevaluasi yang diindentifikasi pada tahap perencanaan.

Tahap 2 : intervensi Focus tahap pelaksanaan tindakan perawatan adalah kegiatan dan pelaksanaan tindakan dari perencanaan untuk memenuhi kebutuhan fisik dan emosional. Pendekatan tindakan keperawatan meliputi tindakan : independen,dependen, dan interdependen.

Tahap 3 : dokumentasi Pelaksanaan tindakan keperawatan harus diikuti oleh pencatatan yang lengkap dan akurat terhadap suatu kejadian dalam proses keperawatan.

\subsubsection{Evaluasi}

Perencanaan evaluasi memuat criteria keberhasilan proses dan keberhasilan tindakan keperawatan. Keberhasilan proses dapat dilihat dengan jalan membandingkan antara proses dengan pedoman/rencana proses tersebut. Sedangkan keberhasilan tindakan dapat dilihat dengan membandingkan antara tingkat kemandirian pasien dalam kehidupan sehari-hari dan tingkat kemajuan kesehatan pasien dengan tujuan yang telah di rumuskan sebelumnya. Sasaran evaluasi adalah sebagai berikut:

1) Proses asuhan keperawatan, berdasarkan criteria/ rencana yang telah disusun.

2) Hasil tindakan keperawatan ,berdasarkan criteria keberhasilan yang telah di rumuskan dalam rencana evaluasi.

Hasil evaluasi Terdapat 3 kemungkinan hasil evaluasi yaitu :

1) Tujuan tercapai,apabila pasien telah menunjukan perbaikan/ kemajuan sesuai dengan criteria yang telah di tetapkan.

2) Tujuan tercapai sebagian,apabila tujuan itu tidak tercapai secara maksimal, sehingga perlu di cari penyebab dan cara mengatasinya.

3) Tujuan tidak tercapai,apabila pasien tidak menunjukan perubahan/kemajuan sama sekali bahkan timbul masalah baru.dalam hal ini perawat perlu untuk mengkaji secara lebih mendalam apakah terdapat data, analisis, diagnosa, tindakan, dan faktor-faktor lain yang 
tidak sesuai yang menjadi penyebab tidak tercapainya tujuan.

Setelah seorang perawat melakukan seluruh proses keperawatan dari pengkajian sampai dengan evaluasi kepada pasien,seluruh tindakannya harus di dokumentasikan dengan benar dalam dokumentasi keperawatan (Stuart, Keliat \& Pasaribu, 2016). 
BAB 3

\section{TINJAUAN KASUS}

\begin{tabular}{|l|l|}
\hline Nama : Ny.F & Kondisi saat MRS: Keluarga pasien \\
Usia : 70 tahun & mengatakan pasien lemas, jantung \\
Tahun no reg : - & berdebar kencang dan pasien \\
Ruangan : - & memiliki riwayat Hipertensi \\
Tgl masuk rs: - & Kondisi saat ini : \\
Tgl pengkajian : 01 Oktober 2021 & Ny. F mengatakan merasa cemas \\
Alamat : Amal Luhur Gg. Supir & dengan kondisinya saat ini. Klien \\
& mengatakan mengeluh khawatir \\
& dengan kondisinya karena sering \\
& mengalami kekambuhan penyakit \\
& yang dialaminya sehingga \\
& membuatnya kesulitan untuk \\
& beraktivitas, Ny.F juga mengatakan \\
& pandangannya mulai rabun, jantung \\
& berdebar kencang dan merasa lemas.
\end{tabular}


1. FAKTOR PREDISPOSISI DAN PRESIPITASI

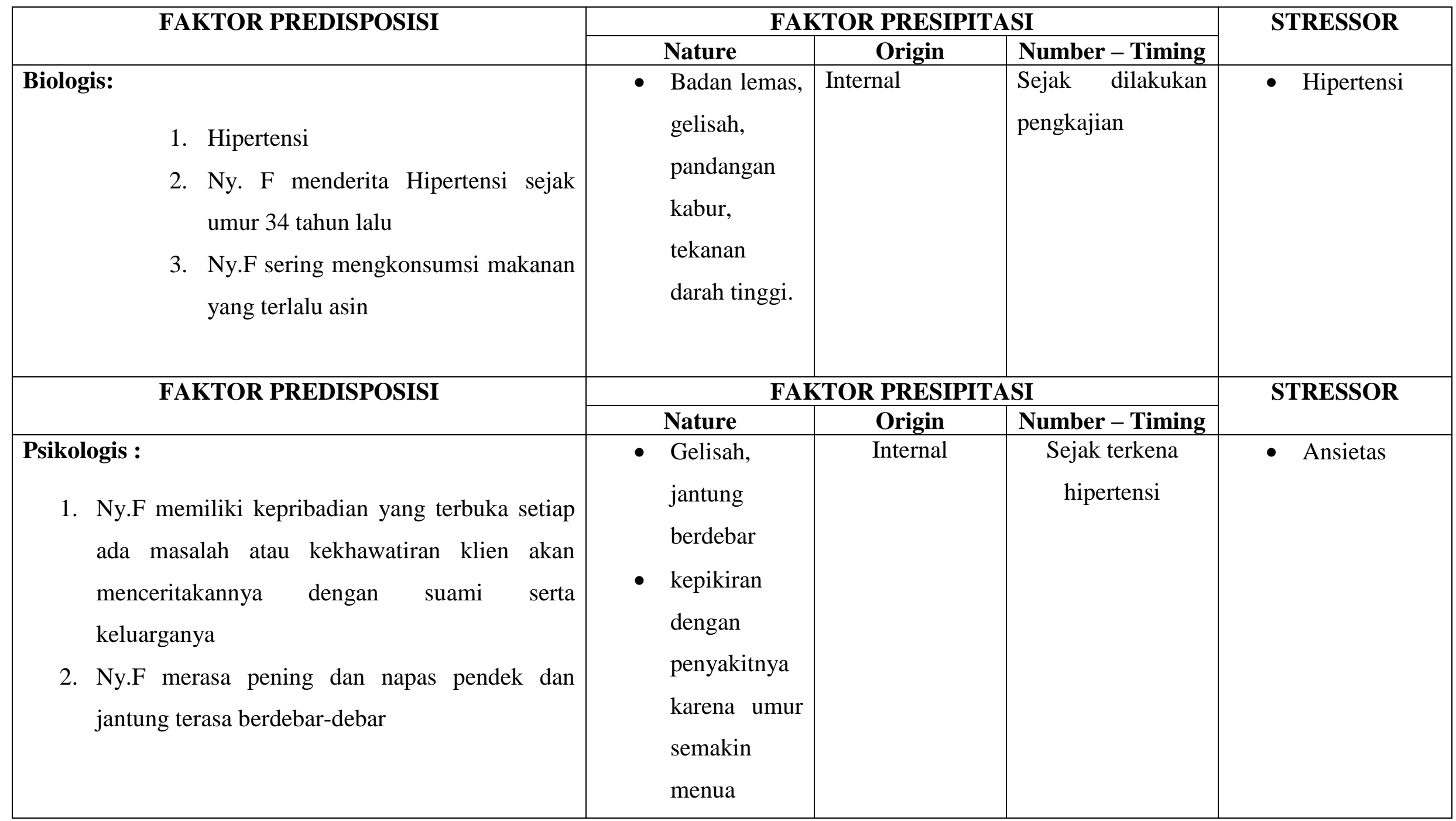




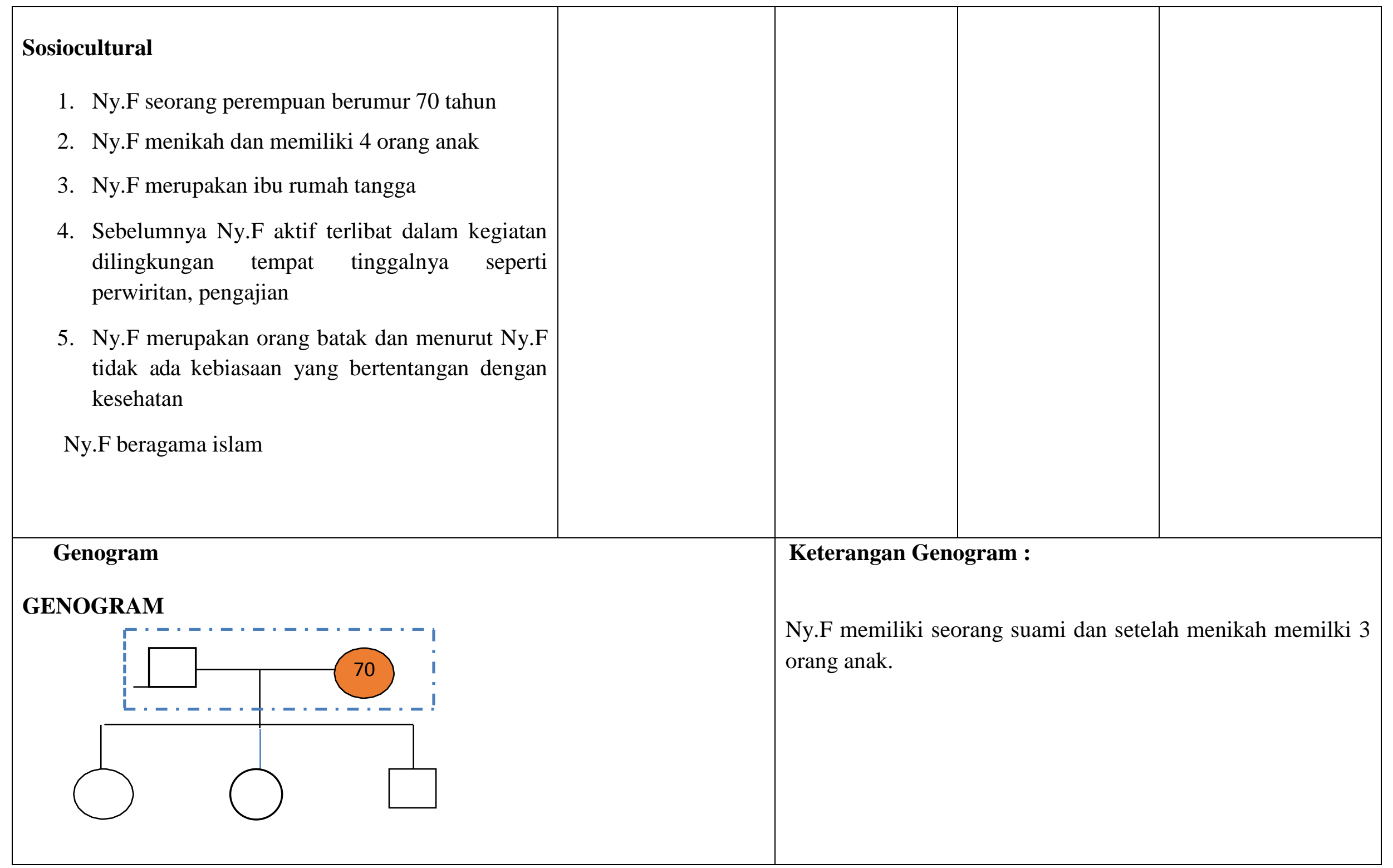


2. PENILAIAN TERHADAP STRESSOR

\begin{tabular}{|l|l|l|l|l|l|}
\hline STRESSOR & KOGNITIF & AFEKTIF & FISIOLOGIS & PERILAKU & DIAGNOSA \\
KEPIAL \\
N
\end{tabular}




\begin{tabular}{|c|c|c|c|c|c|c|}
\hline $\begin{array}{l}\text { BIOLOGIS } \\
\text { Hipertensi }\end{array}$ & $\begin{array}{l}\text { - Menurut Ny.F } \\
\text { penyakit hipertensi } \\
\text { diakibatkan karena } \\
\text { gaya hidup yang } \\
\text { tidak sehat seperti } \\
\text { mengkonsumsi } \\
\text { makanan asin yang } \\
\text { terlalu sering }\end{array}$ & $\begin{array}{l}\text { - Ny.F } \\
\text { merasa } \\
\text { takut } \\
\text { karena } \\
\text { kondisi } \\
\text { penyakit } \\
\text { nya nya } \\
\text { semakin } \\
\text { buruk } \\
\text { dan juga } \\
\text { umurnya } \\
\text { yang } \\
\text { semakin } \\
\text { menua }\end{array}$ & $\begin{array}{l}\text { - } \text { TD naik } \\
\text { - Banyak } \\
\text { Berkeringat } \\
\text { - Nyeri } \\
\text { - Sulit tidur } \\
\text { - penglihatan } \\
\text { rabun } \\
\text { - Ny.F tampak } \\
\text { lemas } \\
\text { - Mukosa bibir } \\
\text { kering } \\
\text { - Konjungtiva } \\
\text { anemis } \\
\text { - Pemeriksaan } \\
\text { TTV } \\
\text { TD: } 150 / 100 \\
\text { mmhg } \\
\mathrm{N}: 88 \times \text { x /menit } \\
\text { P : } 24 \times / \text { menit } \\
\text { S: } 37.5^{\circ} \mathrm{C}\end{array}$ & 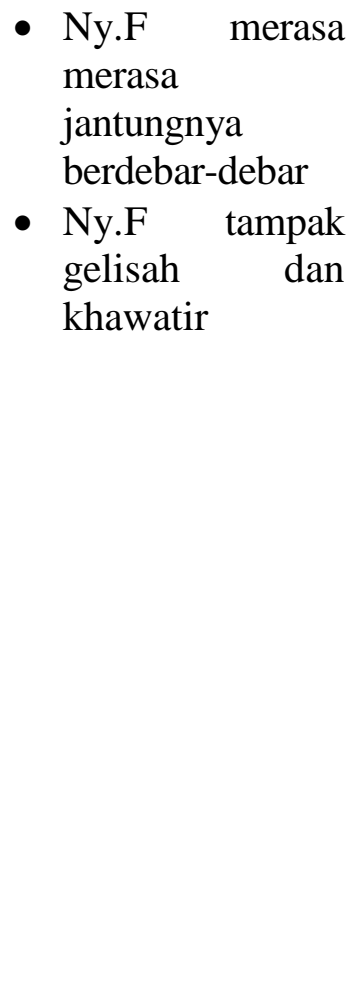 & $\begin{array}{l}\text { - Ny.F ketempat } \\
\text { pelayanan } \\
\text { kesehatan } \\
\text { untuk } \\
\text { mendapatkan } \\
\text { perawatan dan } \\
\text { pengobatan } \\
\text { ditemani oleh } \\
\text { suaminya }\end{array}$ & - Ansietas \\
\hline
\end{tabular}




\begin{tabular}{|c|c|c|c|c|c|c|}
\hline STRESSOR & KOGNITIF & AFEKTIF & FISIOLOGIS & PERILAKU & SOSIAL & $\begin{array}{c}\text { DIAGNOSA } \\
\text { KEPERAWATA } \\
\mathbf{N}\end{array}$ \\
\hline $\begin{array}{l}\quad \text { SOSIAL } \\
\qquad \text { BUDAYA } \\
\text { Sering } \\
\text { memikirkan } \\
\text { bagaimana } \\
\text { kondisi } \\
\text { suaminya jika } \\
\text { suatu saat dia } \\
\text { meninggal } \\
\text { karena } \\
\text { penyakitnya }\end{array}$ & $\begin{array}{l}\text { - Ny.F merasa tidak } \\
\text { berdaya dengan } \\
\text { keadaannya sekarang } \\
\text { yang tidak bisa } \\
\text { melakukan aktivitas } \\
\text { seperti dulu lagi } \\
\text { - merasa } \\
\text { Kasihan } \\
\text { kepada suami } \\
\text { yang harus } \\
\text { menjaga dan } \\
\text { merawat nya }\end{array}$ & $\begin{array}{l}\text { - Merasa } \\
\text { khawatir } \\
\text { dan sedih } \\
\text { kepada } \\
\text { suami } \\
\text { yang } \\
\text { merawatny } \\
\text { a karena } \\
\text { suami juga } \\
\text { sudah tua } \\
\text { dan sakit- } \\
\text { sakitan } \\
\text { - Merasa } \\
\text { bingung } \\
\text { dan } \\
\text { tidak tau } \\
\text { mau } \\
\text { berbuat } \\
\text { apa } \\
\text { dengan } \\
\text { keadaan } \\
\text { sekarang }\end{array}$ & 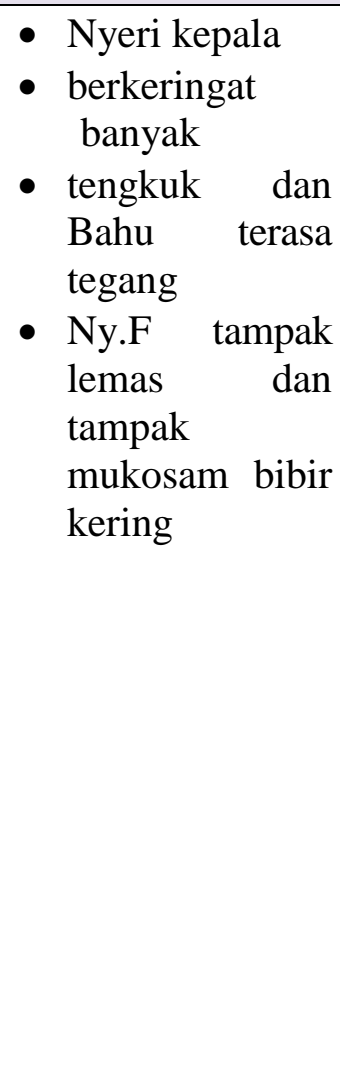 & $\begin{array}{l}\text { - Kontak mata } \\
\text { ada tapi tidak } \\
\text { bertahan lama } \\
\text { - Volume suara } \\
\text { mengecil } \\
\text { Ny.F tampak } \\
\text { gelisah dan } \\
\text { takut }\end{array}$ & $\begin{array}{l}\text { - } \text { Hubungan } \\
\text { Ny.F dengan } \\
\text { suami baik } \\
\text { - hubungan } \\
\text { Ny.F dengan } \\
\text { anak-anaknya } \\
\text { baik } \\
\text { - Ny.F tetap } \\
\text { mengikuti } \\
\text { program } \\
\text { pengobatan }\end{array}$ & $\begin{array}{ll}\text { - Ansietas } \\
\text { ketidakberd } \\
\text { ayaan }\end{array}$ \\
\hline
\end{tabular}


Pohon Diagnosis

\section{Koping in efektiv}

$\widehat{0}$

Ketidak berdayaan

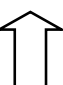

Kecemasa

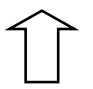

Penyakit Hipertensi + Umur yang menua 


\section{SUMBER KOPING}

\begin{tabular}{|c|c|c|c|c|c|}
\hline $\begin{array}{c}\text { DIAGNOSA } \\
\text { KEPERAWATAN }\end{array}$ & PERSONAL ABILITY & SOSIAL SUPPORT & $\begin{array}{c}\text { MATERIAL } \\
\text { ASSET }\end{array}$ & BELIEF & TERAPI \\
\hline Ansietas & $\begin{array}{l}\text { - Ny.F mampu mengungkapkan } \\
\text { perasaan cemas dan khawatir } \\
\text { yang dia rasakan }\end{array}$ & $\begin{array}{l}\text { - } \text { Ny.F mendapat } \\
\text { perhatian dan } \\
\text { semangat dari } \\
\text { keluarga untuk } \\
\text { kesembuhannya } \\
\text { terutama dari } \\
\text { suaminya }\end{array}$ & $\begin{array}{l}\text { - Ekonomi Ny. } \\
\text { F menengah } \\
\text { - pengobatan } \\
\text { ditanggung } \\
\text { BPJS }\end{array}$ & $\begin{array}{l}\text { - Ny.klien } \\
\text { yakin } \\
\text { dengan } \\
\text { terapi } \\
\text { yang akan } \\
\text { diberikan } \\
\text { dan diajari } \\
\text { akan } \\
\text { menguran } \\
\text { gi } \\
\text { kecemasa } \\
\text { nnya }\end{array}$ & $\begin{array}{l}\text { Terapi } \\
\text { spesialis: } \\
\text { - } \quad \text { Relaksasi } \\
\text { distraksi } \\
\text { - }\end{array}$ \\
\hline
\end{tabular}

\section{MEKANISME KOPING}

\begin{tabular}{|l|c|c|}
\hline \multicolumn{1}{|c|}{ UPAYA YANG DILAKUKAN } & \multicolumn{2}{|c|}{ ANALISA/KESAN } \\
\cline { 2 - 3 } - klien menceritakan bila ada masalah, maka ia akan membicarakan dengan suami & KONSTRUKTIF & DESTRUKTIF \\
dan anaknnya untuk mencari jalan keluarnya & $\checkmark$ & \\
\hline
\end{tabular}


- Bila sakit klien berobat ke pelayanan kesehatan

- Klien taat menjalankan ibadah seperti sholat dan mengaji

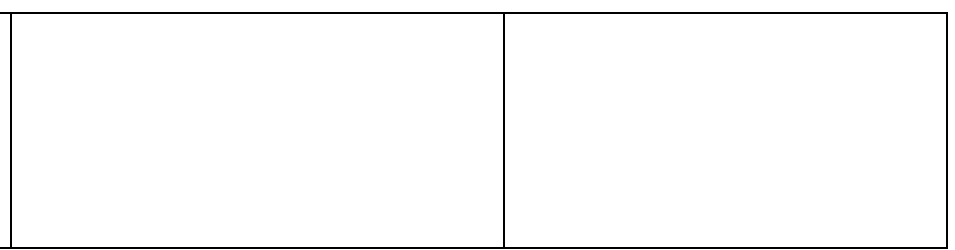

\section{STATUS MENTAL}

\begin{tabular}{|l|l|}
\hline 1. Penampilan & Rapid dan bersih \\
\hline 2. Pembicaraan & Klien berbicara dengan jelas tetapi sekali menarik napas panjang \\
\hline 3. Aktivitas motorik & Klien tampak sedikit tenang tetapi jika membicarakan penyakit klien lemas \\
\hline $\begin{array}{l}\text { 4. } \text { Interaksi selama } \\
\text { wawancara }\end{array}$ & Klien mau menjawab pertanyaan yg diberikan \\
\hline 5. Alam perasaan & Menunjukan ekpresi khawatir dan cemas \\
\hline 6. Afek & Sesuai dengan stimulus yg diberikan \\
\hline 7. Persepsi & Tidak pernah mengalami halusinasi \\
\hline 8. Isi pikir & Normal \\
\hline 9. Proses pikir & Normal \\
\hline 10. Tingkat kesadaran & Normal \\
\hline 11. Daya ingat & Baik \\
\hline 12. Kemampuan berhitung & Baik \\
\hline 13. Penilaian & Klien mampu memberikan keputusan ketika merasa sakit \\
\hline 14. Daya tilik diri & Klien sedkit tidak mengeri dengan penyakitnya \\
\hline
\end{tabular}


6. DIAGNOSA DAN TERAPI

\begin{tabular}{|l|l|}
\hline \multicolumn{1}{|c|}{ DIAGNOSA KEPERAWATAN DAN TERAPI } & \\
KEPERAWATAN & DIAGNOSA MEDISDAN TERAPI MEDIS \\
1. Ansietas & Hipertensi \\
Sp1: Mendiskusikan penyebab, terjadinya proses terjadi, tanda dan \\
gejala dan akibat
\end{tabular}




\begin{tabular}{|c|c|}
\hline IMPLEMENTASI TINDAKAN KEPERAWATAN & EVALUASI (SOAP \\
\hline $\begin{array}{l}\text { Tanggal: } 03 \text { Oktober } 2021 \\
\text { Jam: } 11.00 \text { wib } \\
\text { e. Kaji tanda dan gejala ansietas dan kemampuan klien mengurangi kecemasan } \\
\text { f. Jelaskan tanda dan gejala, penyebab dan akibat dari kecemasan } \\
\text { g. Latihan cara mengatasi kecemasan : } \\
\text { 4) Teknik relaksasi napas dalam } \\
\text { 5) Distraksi : bercakap-cakap hal positif } \\
\text { 6) Hipnotis } 5 \text { jari fokus padahal-hal yang positif } \\
\text { h. Bantu klien melakukan latihan sesuai dengan jadwal kegiatan. }\end{array}$ & $\begin{array}{ll}\text { S : } & \text { Klien mengatakan : merasa lebih tenang tetapi } \\
& \text { belum sepenuhnya cemasnya hilang } \\
\text { - } & \text { Klien mengatakan ia mampu } \\
& \text { mengindentifikasi situasi yang mencetus } \\
& \text { ansietas } \\
\text { O : } & \text { - Klien tampak rileks dan tidak gelisah lagi } \\
\text { - } & \text { Klen mampu menjelaskan kembali penjelasan } \\
& \text { yang sudah diberikan } \\
\text { A : } & \text { Ansietas (+) } \\
\text { P : } & \\
\text { - } & \text { Evaluasi SP-1 dan SP-2 } \\
\text { - } & \text { Latihan cara mengatasi kecemasan : } \\
& \text { - Teknik relaksasi napas dalam } \\
& \text { - Distraksi : bercakap-cakap hal positif } \\
& \text { - Hipnotis } 5 \text { jari fokus padahal-hal yang positif } \\
\text { Bantu } & \text { klien melakukan latihan sesuai dengan jadwal } \\
\text { kegiatan }\end{array}$ \\
\hline
\end{tabular}




\begin{tabular}{|c|c|}
\hline $\begin{array}{l}\text { Tanggal : } 04 \text { September } 2021 \\
\text { Jam : } 10.00 \text { wib } \\
\text { a. Latihan cara mengatasi kecemasan : } \\
\text { - Teknik relaksasi napas dalam } \\
\text { - Distraksi : bercakap-cakap hal positif } \\
\text { - Hipnotis } 5 \text { jari fokus padahal-hal yang positif } \\
\text { b. Bantu klien melakukan latihan sesuai dengan jadwal kegiatan. }\end{array}$ & 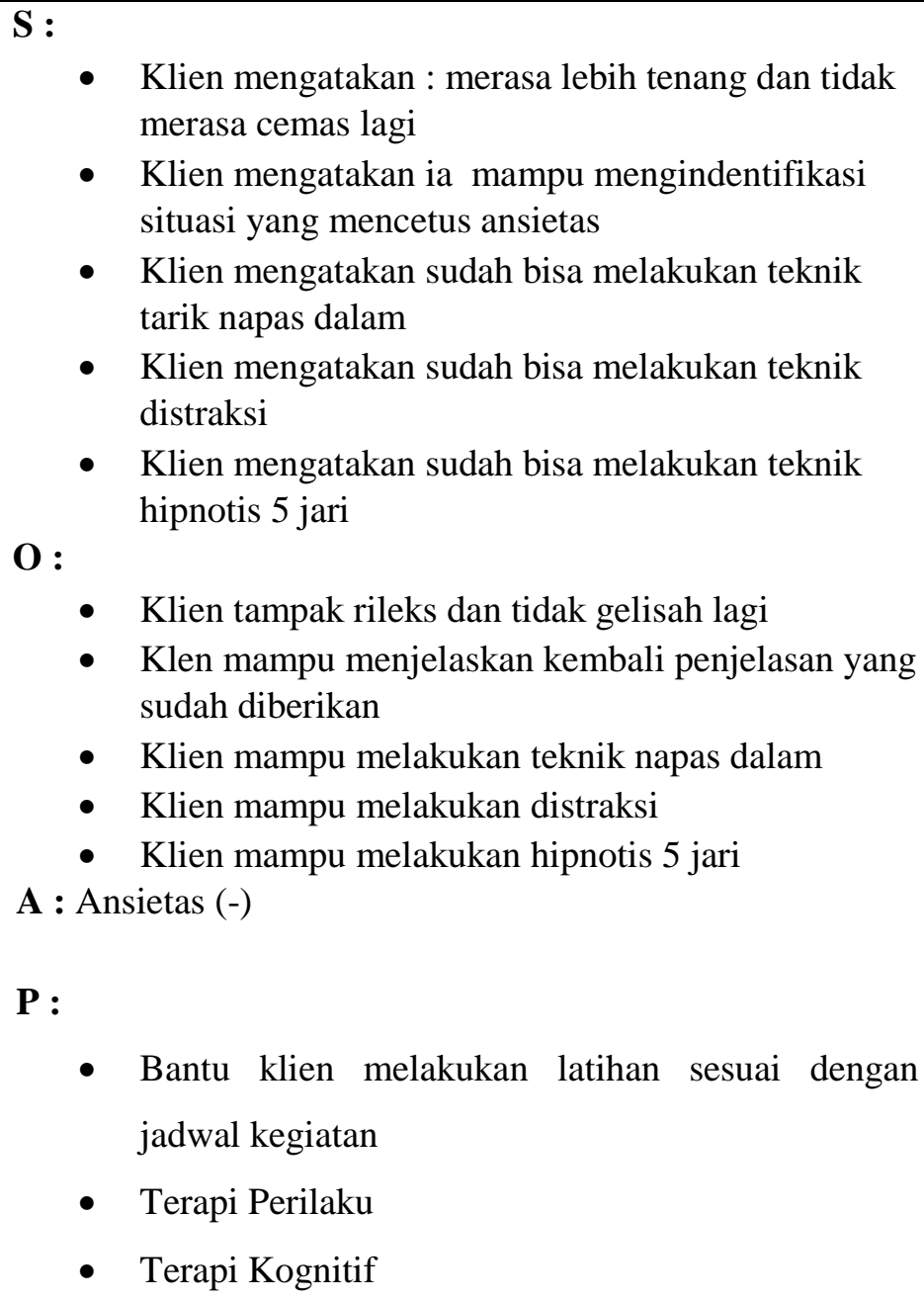 \\
\hline
\end{tabular}




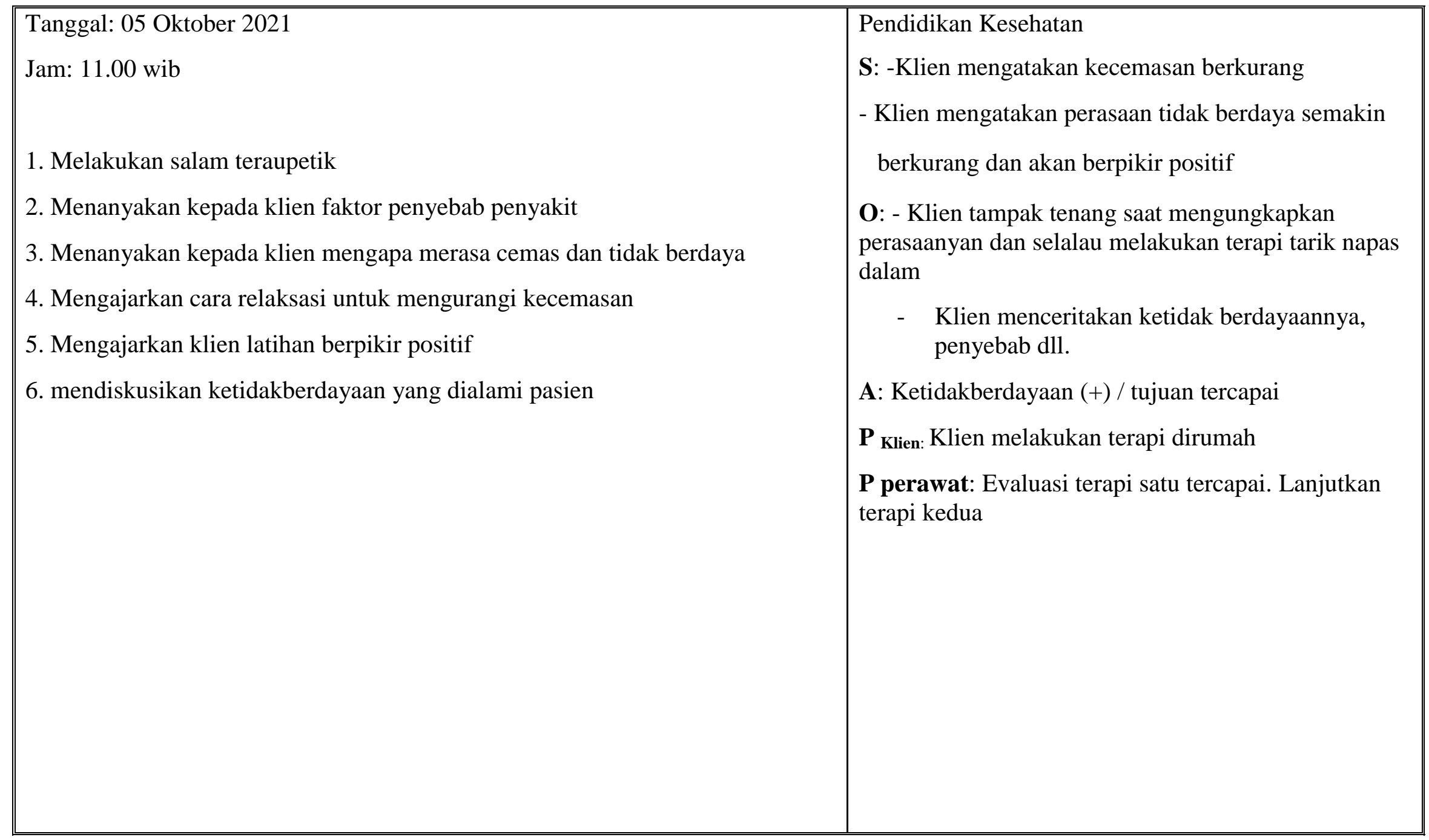




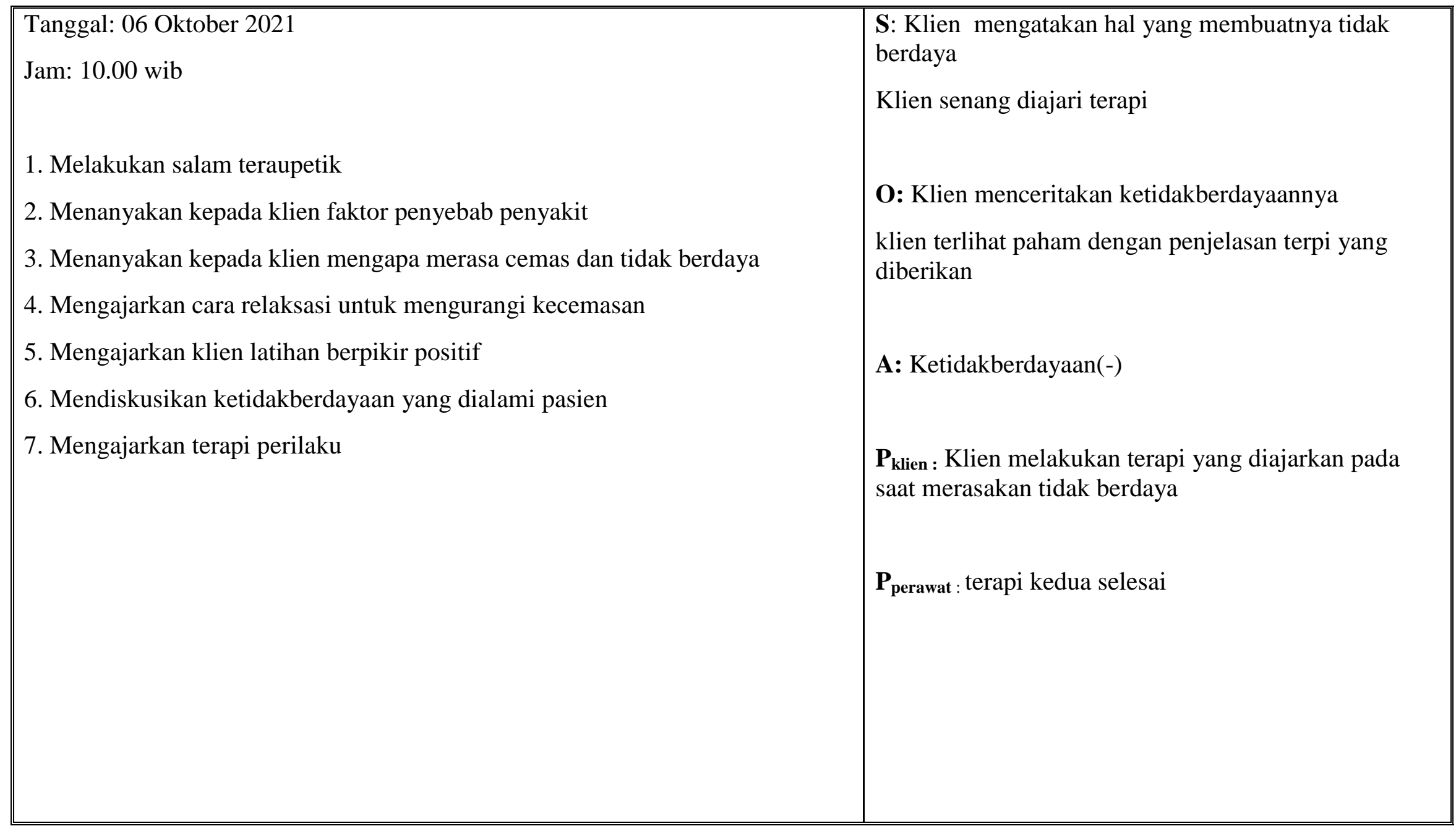




\begin{tabular}{|l|l|}
\hline $\begin{array}{l}\text { Tanggal } 7 \text { Oktober 2021 } \\
\text { jam } 14.00\end{array}$ & $\begin{array}{l}\text { S: Klien mengungkapkan perasaan yang ia rasakan } \\
\text { klien senang diajari terapi }\end{array}$ \\
$\begin{array}{l}\text { 1. Melakukan salam teraupetik } \\
\text { 3. Membina hubungan saling percaya } \\
\text { 4. Mengajarkan klien terapi perilaku dan berpikir positif } \\
\text { O: Klien menceritakan pikiran dan perasaan yang } \\
\text { mengganggu } \\
\text { klien terlihat paham dengan yang dijelaskan }\end{array}$ \\
$\begin{array}{l}\text { A: Koping inefektif berkurang / tujuan tercapai } \\
\text { P: }\end{array}$ \\
$\begin{array}{l}\text { bantu klien melakukan terapi sesuai jadwal } \\
\text { latihan terapi perilaku }\end{array}$
\end{tabular}




\begin{tabular}{|c|c|}
\hline $\begin{array}{l}\text { Tanggal } 08 \text { Oktober } 2021 \\
\text { jam } 14.00\end{array}$ & $\begin{array}{l}\text { S: Klien mengungkapkan perasaan yang ia rasakan } \\
\text { klien senang diajari terapi }\end{array}$ \\
\hline $\begin{array}{l}\text { 1. Melakukan salam teraupetik } \\
\text { 2. Membina hubungan saling percaya } \\
\text { 3. Menanyakan kepada klien tentang perasaannya }\end{array}$ & $\begin{array}{l}\text { O: Klien menceritakan pikiran dan perasaan yang } \\
\text { mengganggu } \\
\text { klien terlihat paham dengan yang dijelaskan }\end{array}$ \\
\hline 4. Mengajarkan klien terapi perilaku dan berpikir positif & $\begin{array}{l}\text { A: Koping inefektif (-) } \\
\text { P: } \\
\quad \bigcirc \quad \text { bantu klien melakukan terapi sesuai jadwal } \\
\quad \bigcirc \quad \text { latihan terapi perilaku } \\
\quad \bigcirc \quad \text { mengajarkan berpikir positif }\end{array}$ \\
\hline
\end{tabular}




\section{BAB 4}

\section{PEMBAHASAN}

Setelah penulis melakukan wawancara yang dilakukan pada pasien penulis mendapatkan hasil yaitu seorang wanita bernama Ny.F. Saat dilakukan pengkajian diruma Ny.F mengatakan sudah menderita Hipertensi sejak dari 34 tahun yang lalu dan selalu merasa cemas dengan keadaannya setiap kali hipertensi nya kambuh. Ny.F mengatakan saat bernapas, napas nya pendek dan terasa sesak, jantung terasa berdebar, saat dilakukan pengukuran tekanan darah didapatkan hasil 150/100 mmHg.

Pasien memiliki tiga orang anak yaitu dua perempuan dan satu laki-laki, pasien tinggal dirumah bersama suaminya saja yang semakin menua. Saat sedang merasa lelah Ny.F bercerita dengan suaminya. Penampilan pasien rapi dan bersih, ramah dan mau menceritakan semua hal yang dialaminya. Saat dilakukan pemberian terapi pasien bisa mengikuti instruksi yang diberikan oleh perawat. Evaluasi yang di lakukan terapi satu berhasil dan dilanjutkan dengan pemberian terapi ke dua.

\subsection{Tahap Pengkajian}

Selama pengkajian dilakukan pengumpulan data dari beberapa sumber, yaitu dari pasien dan tetangga sekitar. Maka penulis melakukan pendekatan kepada pasien melalui komunikasi teraupetik yang lebih terbuka membantu klien untuk memecahkan perasaannya dan juga melakukan observasi kepada pasien. Adapun upaya tersebut yaitu :

a. Melakukan pendekatan dan membina hubungan saling percaya diri pada klien agar klien lebih terbuka dan lebih percaya dengan menggunakan perasaan.

b. Mengadakan pengkajian klien dengan wawancara dalam pengkajian ini, penulis tidak menemukan kesenjangan karena ditemukan hal sama seperti: diteori: Kecemasan adalah keadaan emosi dan pengalaman subyektif individu, tanpa objek yang spesifik karena ketidaktahuan dan mendahului pengalamanya yang baru seperti penyakitnya saat ini 


\subsection{Tahap perencanaan}

Perencanaan dalam proses keperawatan lebih dikenal dengan rencana asuhan keperawatan yang merupakan tahap selanjutnya setelah pangkajian dan penentuan diagnosa keperawatan. Pada tahap perencanaan penulis hanya menyusun rencana tindakan keperawatan sesuai dengan pohon masalah keperawatan yaitu : Kecemasan. Pada tahap ini antara tinjauan teoritis dan tinjaun kasus tidak ada kesenjangan sehingga penulis dapat melaksanakan tindakan seoptimal mungkin dan didukung dengan seringnya bimbingan dengan pembimbing. Secara teoritis digunakan cara strategi pertemuan sesuai dengan diagnosa keperawatan yang muncul saat pengkajian. Adapun upaya yang dilakukan penulis yaitu :

1. Klien mengungkapkan ketidakpastian tentang fluktuasi tingkat energi dan bersikap pasif.

2. Klien menunjukan sikap apatis, depresi terhadap perburukan fisik yang terjadi dengan mengabaikan kepatuhan pasien terhadap program pengobatan

3. Klien mengalami ketergantungan pada orang lain yang dapat mengakibatkan ititabilitas, ketidaksukaan, marah dan rasa bersalah. Klien tidak melakukan praktik perawatan diri ketika ditantang. Klien tidak ikut memantau kemajuan pengobatan. Klien menunjukan ekspresi ketidakpuasan terhadap ketidakmampuan melakukan aktivitas atau tugas sebelumnya. Klien menunjukan ekspresi keraguan tantang performa peran.

\subsection{Tahap Implementasi}

Pada tahap implementasi, penulis hanya mengatasi 3 masalah keperawatan yakni: diagnosa keperawatan Kecemasan, ketidakberdayaan dan koping in efektif merupakan keadaan emosi dan pengalaman subyektif induvidu, tanpa objek spesifik karena ketidaktahuan dan mendahului semua pengalaman yang di alami penyakit Hipertensi 


\subsection{Tahap Evaluasi}

Pada tinjauan teoritis evaluasi yang diharapkan adalah :

a. Membina hubungan saling percaya

b. Mengenali dan mengekspresikan emosinya

c. Mampu mengenal ansietas

d. Mampu mengatasi ansietas melalui teknik releksasi

e. Mampu mengatasi ansietas dengan distraksi

f. Mampu mengatasi ansietas melalui hipnotis lima jari 


\section{BAB 5}

\section{PENUTUP}

\subsection{Kesimpulan}

Berdasarkan uraian pada pembahasan diatas, maka penulis dapat disimpulkan bahwa:

1. Pengkajian dilakukan secara langsung pada klien dan juga dengan menjadikan status klien sebagai sumber informasi yang dapat mendukung data-data pengkajian. Selama proses pengkajian, perawat mengunakan komunikasi terapeutik serta membina hubungan saling percaya antara perawat-klien. Pada kasus Kecemasan : Hipertensi

2. Diagnosa keperawatan yang utama pada klien dengan Kecemasan: Hipertensi

3. Perencanaan dan implementasi keperawatan disesuaikan dengan strategi pertemuan pada pasien.

4. Evaluasi keperawatan yang dilakukan menggunakan metode subyektif, obyektif, assessment dan planing.

\subsection{Saran}

\section{Untuk Keluarga}

Diharapkan agar klien dan keluarga dapat mengerti tentang penyakit hipertensi, dan dapat meningkatkan perilaku hidup sehat dengan tujuan meningkatkan kualitas hidup.

2. Untuk Masyarakat

Diharapkan materi ini dapat dijadikan sebagai bahan ajar dan data untuk menangani dan menghadapi kasus kecemasan pada masalah psikososial. 


\section{DAFTAR PUSTAKA}

1. Akbar \& Tumiwa. (2020). Edukasi Upaya Pencegahan Hipertensi Pada Masyarakat Di Kecamatan Passi Barat Kabupaten Bolaang Mongondow. Jurnal Pengabdian Kepada Masyarakat, 1(3), 154-160

2. Arda, Z. A., \& Mustapa, M. (2018). Hipertensi dan faktor risikonya di puskesmas motolohu kabupaten pohuwato. Gorontalo Journal of Public Health, 1(1), 032-038.

3. Bulechek, G.M., Butcher H.K., Dotcherman J.M. (2016). Nursing Interventions Classification (NIC) 6th Indonesian Edition.Elsevier. Singapore.

4. Hariawan \& Tatisina. (2020). Pelaksanaan Pemberdayaan Keluarga Dan Senam Hipertensi Sebagai Upaya Manajemen Diri Penderita Hipertensi. Jurnal Pengamas Kesehatan Sasambo, 1(2), 75-79

5. Hulu, E. K., \& Pardede, J. A. (2016). Dukungan Keluarga Dengan Tingkat Kecemasan Pasien Pre Operatif Di Rumah Sakit Sari Mutiara Medan. Jurnal Keperawatan, 2(1).

6. Kemenkes RI, (2016). Pedoman Teknis Penemuan Dan Tatalaksana Hipertensi. Jakarta

7. Kaplan, MN., (2016). Kaplan's Clinical Hypertension. 9th ed. USA : Lippincott Williams \& Wilkins. Lancet ; 358 : 1682-1686.

8. Marbun, A., Pardede, J. A., \& Perkasa, S. I. (2019). Efektivitas Terapi Hipnotis Lima Jari terhadap Kecemasan Ibu Pre Partum di Klinik Chelsea Husada Tanjung Beringin Kabupaten Serdang Bedagai. Jurnal Keperawatan Priority, 2(2), 92-99. https://doi.org/10.34012/jukep.v2i2.568

9. Nugraha, A. S. P. H. H. (2020). Pengaruh Essensial Oil dari Biji Pala dan Lavender terhadap Tekanan Darah pada Lansia dengan Hipertensi. NERSMID: Jurnal Keperawatan dan Kebidanan, 3(2), 76-84.

10. Nugroho, N. M. A., Sutejo, S., \& Prayogi, A. S. (2020). Pengaruh Pendidikan Kesehatan Audio Visual Android Terhadap Kecemasan Pasien Pre Operasi Spinal Anestesi di RSU PKU Muhammadiyah Bantul. Jurnal Teknologi Kesehatan (Journal of Health Technology), 16(1), 0815. https://doi.org/10.29238/jtk.v16i1.558

11. Pardede, J. A., \& Simangunsong, M. M. (2020). Family Support With The Level of Preschool Children Anxiety in the Intravenous 
Installation. Jurnal Keperawatan Jiwa (JKJ): Persatuan Perawat Nasional Indonesia, 8(3), 223-234. https://doi.org/10.26714/jkj.8.3.2020.223-234

12. Pardede, J. A. (2020). Standar Asuhan Keperawatan Jiwa Dengan Masalah Kecemasan.

13. Pardede, J. A., Hulu, D. E. S. P., \& Sirait, A. (2021). Tingkat Kecemasan Menurun Setelah Diberikan Terapi Hipnotis Lima Jari pada Pasien Preoperatif. Jurnal Keperawatan, 13(1), 265-272.

https://doi.org/10.37287/jpm.v2i3.128

14. Pardede, J. A., Keliat, B. A., Damanik, R. K., \& Gulo, A. R. B. (2020). Optimalization of Coping Nurses to Overcoming Anxiety in the Pandemic of Covid-19 in Era New Normal. Jurnal Peduli Masyarakat, 2(3), 105112. https://doi.org/10.37287/jpm.v2i3.128

15. Pardede, J., Simanjuntak, G. V., \& Manalu, N.(2020). Effectiveness of deep breath relaxation and lavender aromatherapy against preoperative patient anxiety. Diversity and Equality in Health and Care, 17(4), 168173. doi:10.36648/206 9-5471.17.4.209

16. Pardede, J. A., Sitepu, S. F. A., \& Saragih, M. (2018). The Influence of Deep Breath Relaxation Techniques and Five-Finger Hypnotic Therapy on Preoperative Patient Anxiety. Journal of Psychiatry, 3(1), 1-8.

17. Setyaningsih, R. D. (2015). Studi Prevalensi Dan Kajian Faktor Risiko Hipertensi Pada Lansia Di Desa Tambaksari - Banyumas. Prosiding Seminar Nasional \& Internasional, 1-6.

18. Sofiana, Puratmadja, Kartika, S, Pangulu, Putri. (2018). Upaya Peningkatan Pengetahuan Tentang Hipertensi Melalui Metode Penyuluhan. Jurnal Pemberdayaan, 2(1), 171-176.

19. Setyaningsih, R. D. (2015). Studi Prevalensi Dan Kajian Faktor Risiko Hipertensi Pada Lansia Di Desa Tambaksari - Banyumas. Prosiding Seminar Nasional \& Internasional, 1-6.

20. Stuart, Keliat \& Pasaribu. (2016). Prinsip Dan Praktik Keperawatan Kesehatan Jiwa Stuart. Edisi Indonesia (Buku 1). Singapura:Elsevier

21. Triyanto, E. 2014. Pelayanan Keperawatan Bagi Penderita Hipertensi secara terpadu, Graha Ilmu. Jakarta.

22. Zahara, F. (2017). Hubungan antara kecemasan dengan tekanan darah pada Penderita hipertensi di rsu pku muhammadiyah yogyakarta. Kognisi Jurnal, Vol.2 No.1 Agustus $2017 \quad 2528-4495, \quad 2(1), \quad 42-$ 53. http://dx.doi.org/10.22303/kognisi.2.1.2017.42-53 
